\title{
PENGARUH MODEL PEMBELAJARAN KOOPERATIF TIPE JIGSAW TERHADAP HASIL BELAJAR POKOK BAHASAN MENELADANI KETAATAN MALAIKAT
}

\author{
Meli Sartika Harahap ${ }^{1}$, Ahmad Nizar Rangkuti ${ }^{2}$, Latifa Annum Dalimunthe ${ }^{3}$ \\ 1,2,3 Institut Agama Islam Negeri Padangsidimpuan \\ E-mail: nizarahmad1304@yahoo.com
}

\begin{abstract}
ABSTRAK
Penelitian ini bertujuan untuk mengetahui pengaruh yang signifikan model pembelajaran kooperatif tipe Jigsaw terhadap hasil belajar pokok bahasan meneladani ketaatan malaikatmalaikat Allah Swt kelas VII di SMP Negeri 1 Angkola Timur. Penelitian ini menggunakan pendekatan kuantitatif dengan metode eksperimen. Sampel penelitian ini adalah siswa kelas VII ${ }^{1}$ sebagai kelas eksperimen dan kelas $\mathrm{VII}^{2}$ sebagai kelas kontrol. Instrumen penelitian ini adalah tes hasil belajar yang valid dan reliable. Hasil penelitian menunjukkan bahwa terdapat pengaruh yang signifikan model pembelajaran kooperatif tipe Jigsaw terhadap hasil belajar siswa. Hal ini ditunjukkan dari hasil pengujian hipotesis dengan menggunakan uji-t menghasilkan nilai $t_{\text {hitung }}>t_{\text {tabel }}$ yaitu 3,80>1,98 dengan taraf signifikansi 0,05 .
\end{abstract}

\section{Kata Kunci: Model Pembelajaran; Kooperatif; Tipe Jigsaw; Meneladani ketaatan malaikat; Hasil Belajar}

\section{PENDAHULUAN}

Dalam mencapai tujuan pendidikan nasional diperlukan seperangkat kurikulum yang menunjang untuk diberikan kepada anak didik melalui kegiatan pengajaran yang diselenggarakan pada semua satuan dan jenjang pendidikan menengah dan pendidikan tinggi. Kurikulum sebagai jembatan untuk menuju tujuan pada tiap satuan pendidikan diuraikan atas beberapa tahap pelajaran bagi sekolah dan beberapa mata kuliah untuk perguruan tinggi salah satunya adalah Pendidikan Agama Islam.

Pendidikan Agama Islam dimaksudkan untuk membentuk peserta didik menjadi manusia yang beriman dan bertaqwa kepada Allah SWT dan berakhlak mulia serta meningkatkan potensi spiritual, karena Pendidikan Agama Islam adalah modal dasar yang merupakan tenaga penggerak yang tidak ternilai harganya. Proses pembelajaran tersebut merupakan suatu proses yang baik dan mengkaitkan berbagai aspek yang saling berkaitan. Oleh karena itu untuk menciptakan pembelajaran yang kreatif, diperlukan keterampilan. Diantaranya adalah keterampilan membelajarkan dan keterampilan mengajar. ${ }^{1}$

\footnotetext{
* Corresponding Author

${ }^{1}$ E. Mulyasa, Menjadi Guru Profesional: Menciptakan Pembelajaran Kreatif Dan Menyenangkan (Bandung: PT Remaja Rosdakarya, 2005), h.1.
} 
Pada umumnya rendahnya hasil belajar Pendidikan Agama Islam mengakibatkan permasalahan yang timbul dalam proses pembelajaran yang mungkin muncul dari siswa dan model pembelajaran yang dibawakan oleh guru. Satu usaha untuk mengimbangi tujuan menyelesaikan masalah serta memupuk kemahiran tentang model pembelajaran untuk meningkatkan hasil belajar siswa. Model pembelajaran adalah seluruh rangkaian penyajian meteri ajar yang meliputi segala aspek sebelum sedang dan sesudah pembelajaran yang dilakukan guru serta segala fasilitas yang terkait untuk digunakan secara langsung atau tidak langsung dalam proses belajar mengajar. ${ }^{2}$ Slavin menyebutkan bahwa model pembelajaran kooperatif menggalakkan siswa berinteraksi secara aktif dan positif dalam kelompok. ${ }^{3}$ Ada beberapa variasi jenis model dalam pembelajaran kooperatif yang digunakan dalam memecahkan masalah pembelajaran dalam meningkatkan hasil belajar siswa salah satunya adalah model pembelajaran kooperatif tipe Jigsaw.

Beberapa hasil penelitian yang telah dilakukan menunjukkan bahwa model pembelajaran kooperatif tipe jigsaw memiliki kontribusi positif terhadap hasil belajar. Hasil penelitian Muhammad $(2015)^{4}$ menyebutkan bahwa terdapat pengaruh yang signifikan model pembelajaran kooperatif tipe Jigsaw terhadap hasil belajar Pendidikan Agama Islam pada materi Zakat. Selanjutnya, hasil penelitian Susanti (2016) ${ }^{5}$ menyebutkan bahwa hasil belajar Pendidikan Agama Islam Pokok Bahasan Beriman Kepada Malaikat Allah dengan mmenggunakan metode Jigsaw dapat meningkat. Dari kedua hasil penelitian di atas, dapat diduga bahwa metode Jigsaw potensial dalam meningkatkan hasil belajar siswa pada materi Pendidikan Agama Islam.

Teori yang mendasari pembelajaran ini adalah teori belajar konstruktivisme. Teori konstruktivisme menuntut peserta didik untuk membangun pengetahuan yang dimiliki dan dapat menemukan ide-ide untuk mendorong mereka agar lebih aktif untuk belajar. Teori konstruktivisme adalah pembelajaran yang bersifat generatif, yaitu suatu yang harus diketahui

\footnotetext{
2 Istarani, 58 Model Pembelajaran Inovatif (Medan: Media Persada, 2014), h.1.

${ }^{3}$ Rusman, Model-Model Pembelajaran Mengembangkan Profesionalisme Guru, Kedua (Jakarta: PT Raja Grafindo Persada, 2013), h.201.

${ }^{4}$ Muhammad, 2015“Pengaruh Model Pembelajran Kooperatif Jigsaw Terhadap Tingkat Pemahaman Siswa Tentang Materi Zakat Pada Mata Pelajaran Pendidikan Agama Islam Di Kelas VIII SMP Sulthan Bogor Tahun Ajaran 2015/2016"

5 Susi Susanti, 2016 "Peningkatan Prestasi Belajar Pai Meteri Beriman Kepada Malaikat Allah Menggunakan Metode Jigsaw Pada Siswa Kelas VII B Semester 2 SMP Negeri 3 Ungaran Kabupaten Semarang Tahun Pelajaran 2016/2017"
} 
makna atau tindakan dari apa yang telah dipelajari. Konsep utama teori konstruktivisme adalah peserta didik dituntut untuk lebih aktif dalam memahami tentang apa yang dipelajarinya.

Berdasarkan latar belakang di atas, maka tujuan yang ingin dicapai peneliti dalam penelitian ini adalah untuk mengetahui pengaruh model Pembelajaran Kooperatif Tipe Jigsaw terhadap hasil belajar siswa mata pelajaran Pendidikan Agama Islam pokok bahasan meneladani ketaatan malaikat-malaikat Allah SWT di kelas VII SMP Negeri 1 Angkola Timur.

\section{METODE PENELITIAN}

Jenis penelitian yang digunakan adalah penelitian kuantitatif dengan menggunakan metode eksperimen. ${ }^{6}$ Ibnu Hajar mengemukakan "metode eksperimen adalah metode penelitian yang digunakan untuk menyelidiki pengaruh satu variabel terhadap variabel lain. ${ }^{7}$ Peneliti ingin melihat seberapa jauh pengaruh pembelajaran kooperatif tipe Jigsaw terhadap hasil belajar siswa pada pokok bahasan meneladani ketaatan malaikat-malaikat Allah SWT.

Desain eksperimen yang digunakan adalah non randomized control group pre test pos test design. Sebab penelitian ini mengujicobakan dua kelompok dengan membandingkan hasil dari setiap kelompok yang terdiri dari kelas eksperimen dan kelas kontrol. ${ }^{8}$ Langkah-langkah umum dalam penelitian eksperimen ini adalah penelitian dan pengumpulan informasi, perencanaan, penentuan populasi dan sampel, variabel penelitian, instrumen penelitian, teknik pengumpulan data, validasi dan reliabilitas yakni: validitas instrumen, reliabilitas, tingkat kesukaran soal, dan daya pembeda. Teknik analisis data yakni: uji normalitias, uji homogenitas dan uji hipotesis.

\section{HASIL PENELITIAN}

\section{Hasil penelitian}

a. Hasil Pre-test Peserta Didik Kelas Eksperimen Dan Kontrol Dengan Menggunakan Kooperatif Jigsaw

Dalam proses pembelajaran yang menggunakan kooperatif jigsaw dimulai dengan pemberian pretes, kemudian peserta didik dibagi ke dalam kelompok belajar secara heterogen dan setiap kelompok diberi tugas untuk mendiskusikan materi mengenai

\footnotetext{
${ }^{6}$ Suharsimi Arikunto, Manajemen Penelitian (Jakarta: PT. Rineka Cipta, 2013), 207.

7 Ibnu Hajar, Dasar-Dasar Metodologi Penelitian Kuantitatif Dalam Pendidikan (Jakarta: Raja Grafindo Persada, 1999), 321.

8 Ahmad Nizar Rangkuti, Metode Penelitian Pendidikan Pendekatan Kuantitafi, Kualitatif, PTK, Dan Penelitian Pengembangan (Bandung: Citaputaka Media, 2016), 81.
} 
meneladani ketaatan malaikat-malaikat Allah SWT kemudian hasil yang didiskusikan dipresentasikan di depan kelas dan di akhiri dengan post-test. Hal ini dilakukan untuk mengukur penguasaan peserta didik pada materi meneladani ketaatan malaikat-malaikat Allah SWT.

Tabel 1.

Nilai Pre-test Kelas Eksperimen

\begin{tabular}{|r|l|r|}
\hline No & Nama Siswa & Nilai \\
\hline 1 & Joyanda thahery R & 60 \\
\hline 2 & Ade pratama & 65 \\
\hline 3 & Hendra syaputra T & 65 \\
\hline 4 & Yasir & 65 \\
\hline 5 & Ayu wulan sari & 65 \\
\hline 6 & Gunawan & 70 \\
\hline 7 & Azil prayetno & 50 \\
\hline 8 & Elide yanti siregar & 45 \\
\hline 9 & Alwi alfauzi & 45 \\
\hline 10 & Asfi raihan R & 60 \\
\hline & Dina heriyani & \\
11 & siagian & 60 \\
\hline 12 & Fitri rahmadani S & 70 \\
\hline 13 & Alya arisya & 55 \\
\hline 14 & Sahara harahap & 55 \\
\hline 15 & Deya saputri H & 50 \\
\hline 16 & Benny hidayat & 60 \\
\hline 17 & Ira yus niar & 70 \\
\hline 18 & Adelia pulungan & 80 \\
\hline 19 & Hoirun saleh & 60 \\
\hline 20 & Laila azmi & 70 \\
\hline 21 & Ganti hasbullah & 65 \\
\hline 22 & Mahadi ansyah & 50 \\
\hline 23 & Sri utami lubis & 35 \\
\hline 24 & Winda Sandra & 55 \\
\hline 25 & Ali ibrahim S & 60 \\
\hline 26 & Nia Angelija & 50 \\
\hline 27 & Nova Andriani & 35 \\
\hline 28 & Dyo ade P & 65 \\
\hline & & \\
\hline
\end{tabular}


Data dideskripsikan untuk memperoleh gambaran tentang karakteristik variable penelitian. Deskripsi data menyajikan nilai tinggi, nilai rendah, mean, varians dan rentang data.

\section{Tabel 2}

Data Hasil Belajar PAI Pre-test Siswa Pada Kelas Eksperimen

\begin{tabular}{|c|c|}
\hline Distribusi & Nilai \\
\hline Nilai Tertinggi & 80 \\
\hline Nilai Terendah & 35 \\
\hline Rentangan & 45 \\
\hline Banyak Kelas & 8 \\
\hline Panjang Kelas & 6 \\
\hline Mean & 57.8 \\
\hline Standar Deviasi & 9.768 \\
\hline Jumlah Sampel & 28 \\
\hline
\end{tabular}

Tabel 3

Distribusi Frekuensi Pre-test Kelas Eksperimen

\begin{tabular}{|r|l|r|r|}
\hline \multicolumn{1}{|c|}{ No } & $\begin{array}{c}\text { Banyak } \\
\text { Kelas }\end{array}$ & \multicolumn{1}{|l|}{ Frekuensi } & Frek.Kom \\
\hline 1 & $35-42$ & 2 & $7 \%$ \\
\hline 2 & $43-50$ & 6 & $21 \%$ \\
\hline 3 & $51-58$ & 3 & $11 \%$ \\
\hline 4 & $59-65$ & 12 & $43 \%$ \\
\hline 5 & $66-73$ & 4 & $14 \%$ \\
\hline 6 & $74-80$ & 1 & $4 \%$ \\
\hline & & 28 & $100 \%$ \\
\hline
\end{tabular}

Gambar 1

Histogram Pre-test Pada Kelas Eksperimen

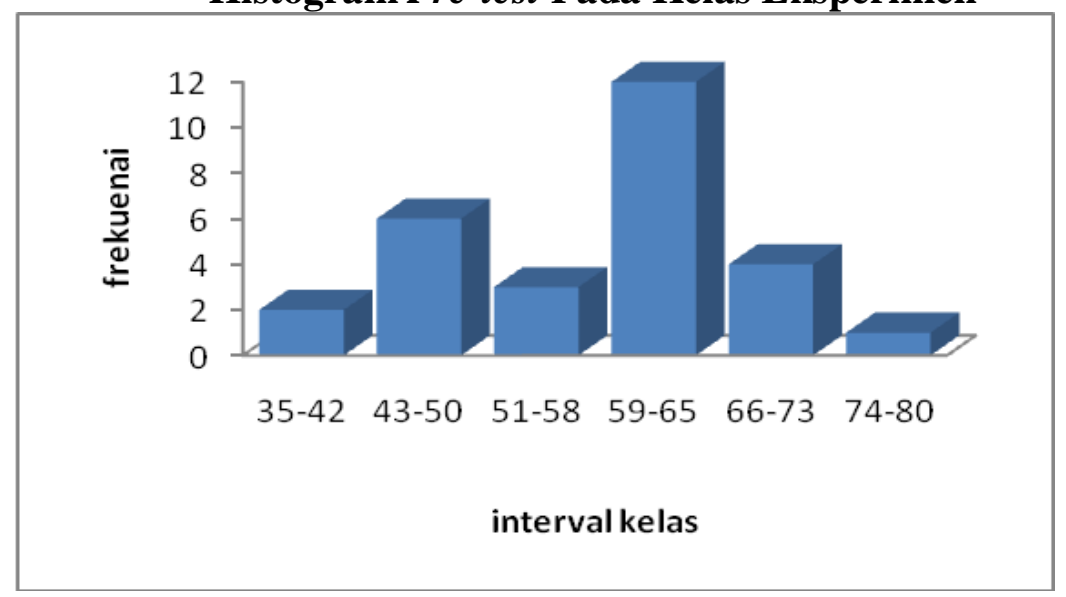


Berdasarkan tabel distribusi frekuensi di atas, dapat diketahui bahwa siswa yang paling sedikit adalah siswa yang kemampuan tinggi yaitu 1 orang siswa yang memperoleh nilai interval 74-80. sedangkan siswa yang berkemampuan rendah ada 2 orang siswa yang memperoleh nilai interval 35-42, dan siswa yang berkemampuan sedang ada 3 orang siswa yaitu memperoleh nilai interval 51-58.

\section{Tabel 4}

Nilai Pre-test Kelas Kontrol

\begin{tabular}{|c|l|c|}
\hline No & \multicolumn{1}{|c|}{ Siswa } & nilai \\
\hline 1 & Apsal Pasaribu & 65 \\
\hline 2 & Annisa Hasrani & 65 \\
\hline 3 & Aril Syahputra & 75 \\
\hline 4 & Aanda Pratama & 65 \\
\hline 5 & Asma Rini F & 65 \\
\hline 6 & Aulia Putri A P & 70 \\
\hline 7 & Erliana Putri H & 55 \\
\hline 8 & Andi Padila H & 45 \\
\hline 9 & Iswandi Siregar & 50 \\
\hline 10 & Marsipa Nasution & 55 \\
\hline 11 & Nurhamidah Harahap & 70 \\
\hline 12 & Parla Yuherman C & 60 \\
\hline 13 & Roy Triadi & 50 \\
\hline 14 & Ryan Syahputra H & 65 \\
\hline 15 & Salsa Aulia & 50 \\
\hline 16 & Ucok Suwardi H & 60 \\
\hline 17 & Winda Sari H & 60 \\
\hline 18 & Winda Ramadani & 75 \\
\hline 19 & Yesi Amelia P & 50 \\
\hline 20 & Raja Aidil H & 65 \\
\hline 21 & Sakinah Mawaddah S & 65 \\
\hline 22 & Raja Regen M & 50 \\
\hline 23 & Putri Amelia & 35 \\
\hline 24 & Risna Handayani H & 50 \\
\hline 25 & Olivia Desmawani & 55 \\
\hline 26 & Reva Rico S & \\
\hline 27 & Runus Ramadhani H & 40 \\
\hline 28 & Parningotan & \\
\hline & & 55 \\
\hline
\end{tabular}


Data dideskripsikan untuk memperoleh gambaran tentang karakteristik variable penelitian. Deskripsi data menyajikan nilai tinggi, nilai rendah, mean, varians dan rentang data.

\section{Tabel 5}

Data Pre-test Kelas Kontrol

\begin{tabular}{|c|c|}
\hline Distribusi & Nilai \\
\hline Nilai Tertinggi & 75 \\
\hline Nilai Terendah & 35 \\
\hline Rentangan & 40 \\
\hline Banyak Kelas & 7 \\
\hline Panjang Kelas & 6 \\
\hline Mean & 59.91 \\
\hline Standar Deviasi & 10.45 \\
\hline Jumlah Sampel & 28 \\
\hline
\end{tabular}

Tabel 6

Distribusi Frekuensi Pre-test Kelas Kontrol

\begin{tabular}{|c|c|c|c|}
\hline No & banyak kelas & Frekuensi & frek.kom \\
\hline 1 & $34-40$ & 2 & $7 \%$ \\
\hline 2 & $41-47$ & 1 & $4 \%$ \\
\hline 3 & $48-54$ & 5 & $18 \%$ \\
\hline 4 & $55-60$ & 4 & $14 \%$ \\
\hline 5 & $61-68$ & 10 & $36 \%$ \\
\hline 6 & $69-75$ & 6 & $21 \%$ \\
\hline & & 28 & $100 \%$ \\
\hline
\end{tabular}

Gambar 2

Histogram Pre-test Kelas Kontrol

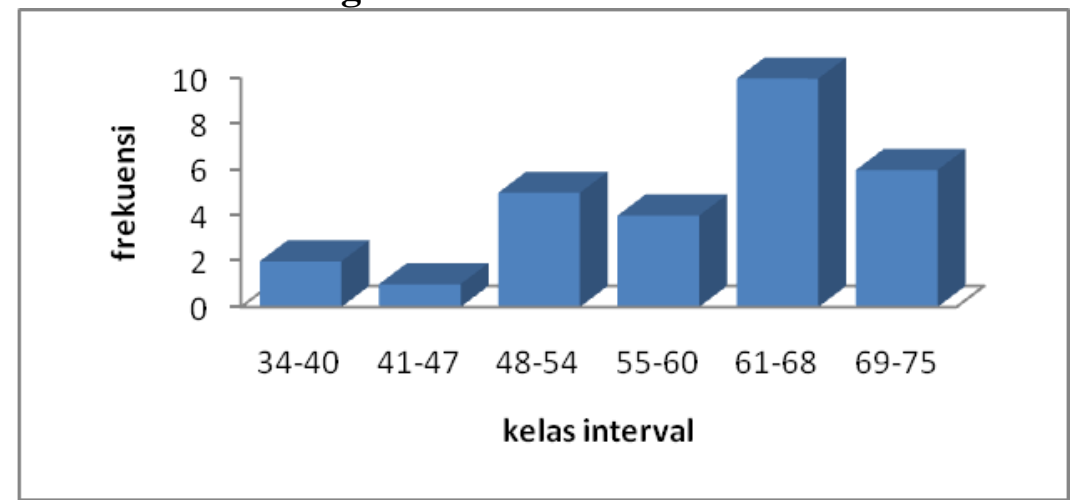

Berdasarkan tabel distribusi frekuensi di atas, dapat diketahui bahwa siswa yang berkemampuan sedang yaitu 5 orang siswa memperoleh nilai interval 48-54. Sedangkan 
siswa yang berkemampuan rendah ada 2 orang siswa yang memperoleh nilai pada interval 34-40 dan siswa yang berkemampuan tinggi ada 6 orang siswa yaitu memperoleh nilai interval 69-75.

\section{b. Hasil Post-test Kelas Eksperimen dan Kontrol Dengan Menggunakan Kooperatif Jigsaw}

Hasil nilai yang diperoleh siswa dari post-test yang dilakukan pada kelas eksperimen kooperatif jigsaw dan post-test kelasa kontrol dapat ditunjukkan pada tabel berikut ini.

\section{Tabel 7}

Nilai Post-test Kelas Eksperimen

\begin{tabular}{|c|c|c|}
\hline No & Siswa & Nilai \\
\hline 1 & Joyanda Thahery R & 70 \\
\hline 2 & Ade Pratama & 80 \\
\hline 3 & Hendra Syaputra T & 90 \\
\hline 4 & Yasir & 85 \\
\hline 5 & Ayu Wulan Sari & 75 \\
\hline 6 & Gunawan & 90 \\
\hline 7 & Azil Prayetno & 65 \\
\hline 8 & Elide Yanti Siregar & 80 \\
\hline 9 & Alwi Alfauzi & 100 \\
\hline 10 & Asfi Raihan R & 70 \\
\hline 11 & Dina Heriyani Siagian & 70 \\
\hline 12 & Fitri Rahmadani S & 95 \\
\hline 13 & Alya Arisya & 75 \\
\hline 14 & Sahara Harahap & 75 \\
\hline 15 & Deya Saputri H & 60 \\
\hline 16 & Benny Hidayat & 70 \\
\hline 17 & Ira Yus Niar & 75 \\
\hline 18 & Adelia Pulungan & 70 \\
\hline 19 & Hoirun Saleh & 90 \\
\hline 20 & Laila Azmi & 90 \\
\hline 21 & Ganti Hasbullah & 75 \\
\hline 22 & Mahadi Ansyah & 90 \\
\hline 23 & Sri Utami Lubis & 60 \\
\hline 24 & Winda Sandra & 75 \\
\hline 25 & Ali Ibrahim $S$ & 80 \\
\hline 26 & Nia Angelija & 60 \\
\hline 27 & Nova Andriani & 70 \\
\hline 28 & Dyo Ade P & 80 \\
\hline
\end{tabular}


Data di deskripsikan untuk memperoleh gambaran tentang karakteristik variable penelitian. Deskripsi data menyajikan nilai tinggi, nilai rendah, mean, varians dan rentang data.

\section{Tabel 8}

Data Hasil Post-tes Kelas Eksperimen

\begin{tabular}{|c|c|}
\hline Distribusi & Nilai \\
\hline Nilai Tertinggi & 100 \\
\hline Nilai Terendah & 60 \\
\hline Rentangan & 40 \\
\hline Banyak Kelas & 6 \\
\hline Panjang Kelas & 7 \\
\hline Mean & 73.23 \\
\hline Standar Deviasi & 13.65 \\
\hline Jumlah Sampel & 28 \\
\hline
\end{tabular}

Nilai yang diperoleh siswa dari postest yang dilakukan pada kelas eksperimen kooperatif jigsaw dapat ditunjukkan pada tabel berikut.

\section{Tabel 9}

Distribusi Frekuensi Post-test Kelas Eksperimen

\begin{tabular}{|r|l|r|r|}
\hline No & Banyak Kelas & Frekuensi & Frek.Kom \\
\hline 1 & $60-66$ & 4 & $14 \%$ \\
\hline 2 & $67-72$ & 7 & $25 \%$ \\
\hline 3 & $73-79$ & 6 & $21 \%$ \\
\hline 4 & $80-86$ & 4 & $14 \%$ \\
\hline 5 & $87-93$ & 5 & $18 \%$ \\
\hline 6 & $94-100$ & 2 & $7 \%$ \\
\hline & & 28 & $100 \%$ \\
\hline
\end{tabular}

Gambar 3

Histogram Nilai Pos-test Kelas Eksperimen

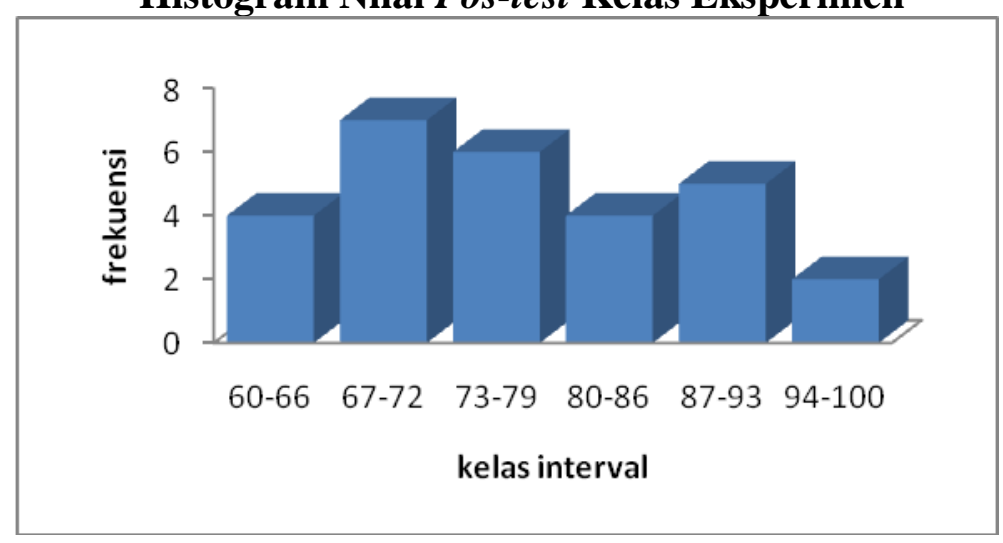


Berdasarkan tabel distribusi frekuensi di atas, dapat diketahui bahwa siswa yang berkemampuan sedang, yaitu 6 orang siswa yang memperoleh nilai interval 73-79. Sedangkan siswa yang berkemampuan rendah ada 4 orang siswa yang memperoleh nilai pada nilai interval 60-66. Dan siswa yang berkemampuan tingggi ada 2 orang siswa yaitu memperoleh nilai 94-100.

Tabel 10

Nilai Post-test Kelas Kontrol

\begin{tabular}{|c|c|c|}
\hline No & Nama Siswa & Nilai \\
\hline 1 & Apsal Pasaribu & 65 \\
\hline 2 & Annisa Hasrani & 75 \\
\hline 3 & Aril Syahputra & 45 \\
\hline 4 & Aanda Pratama & 90 \\
\hline 5 & Asma Rini F & 80 \\
\hline 6 & Aulia Putri A P & 55 \\
\hline 7 & Erliana Putri $\mathrm{H}$ & 65 \\
\hline 8 & Andi Padila $\mathrm{H}$ & 65 \\
\hline 9 & Iswandi Siregar & 90 \\
\hline 10 & Marsipa Nasution & 55 \\
\hline 11 & Nurhamidah Harahap & 80 \\
\hline 11 & Parla Yuherman C & 60 \\
\hline 13 & Roy Triadi & 60 \\
\hline 14 & Ryan Syahputra H & 60 \\
\hline 15 & Salsa Aulia & 80 \\
\hline 16 & Ucok Suwardi H & 65 \\
\hline 17 & Winda Sari H & 85 \\
\hline 18 & Winda Ramadani & 80 \\
\hline 19 & Yesi Amelia P & 80 \\
\hline 20 & Raja Aidil H & 85 \\
\hline 21 & Sakinah Mawaddah S & 60 \\
\hline 22 & Raja Regen M & 50 \\
\hline 23 & Putri Amelia & 75 \\
\hline 24 & Risna Handayani H & 75 \\
\hline 25 & Olivia Desmawani & 70 \\
\hline 26 & Reva Rico S & 70 \\
\hline 27 & Runus Ramadhani H & 50 \\
\hline 28 & Parningotan & 45 \\
\hline
\end{tabular}

Data dideskripsikan untuk memperoleh gambaran tentang karakteristik variabel penelitian. Deskripsi data menyajikan nilai tinggi, nilai rendah, mean, varians dan rentang data. 
Tabel 11

Data Post-test Kelas Kontrol

\begin{tabular}{|c|c|}
\hline Distribusi & Nilai \\
\hline Nilai Tertinggi & 90 \\
\hline Nilai Terendah & 45 \\
\hline Rentangan & 45 \\
\hline Banyak Kelas & 6 \\
\hline Panjang Kelas & 8 \\
\hline Mean & 68.214 \\
\hline Standar Deviasi & 13.706 \\
\hline Jumlah Sampel & 28 \\
\hline
\end{tabular}

Tabel 12

Distribusi Frekuensi Post-test Kelas Kontrol

\begin{tabular}{|c|c|c|c|}
\hline no & banyak kelas & frekuensi & frek.kom \\
\hline 1 & $45-52$ & 4 & $14 \%$ \\
\hline 2 & $53-60$ & 6 & $21.43 \%$ \\
\hline 3 & $61-68$ & 4 & $14.29 \%$ \\
\hline 4 & $69-76$ & 5 & $17.86 \%$ \\
\hline 5 & $77-84$ & 5 & $17.86 \%$ \\
\hline 6 & $85-92$ & 4 & $14.29 \%$ \\
\hline & & 28 & $100 \%$ \\
\hline
\end{tabular}

\section{Gambar 4}

\section{Histogram Post-test Pada Kelas Kontrol}

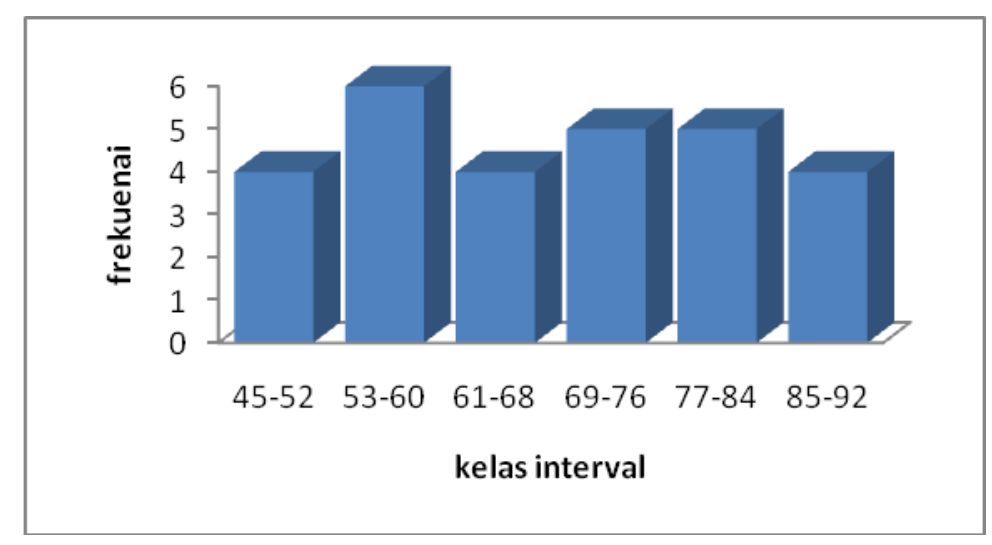


Berdasarkan tabel distribusi frekuensi di atas, dapat diketahui bahwa siswa yang berkemampuan sedang, yaitu 4 orang siswa yang memperoleh nilai interval 61-68. Sedangkan siswa yang berkemampuan rendah ada 4 orang siswa yang memperoleh nilai interval 45-52 dan siswa yang berkemampuan tinggi ada 4 orang siswa yaitu memperoleh nilai interval 85-92.

Data postest menunjukkan bahwa kedua kelas eksperimen menunjukkan bahwa kedua kelas eksperimen kontrol memperoleh nilai rata-rata nilai yang berbeda.

\section{Gambar 5}

Histogram Nilai Hasil Belajar Siswa

Kelas Eksperimen dan Kontrol

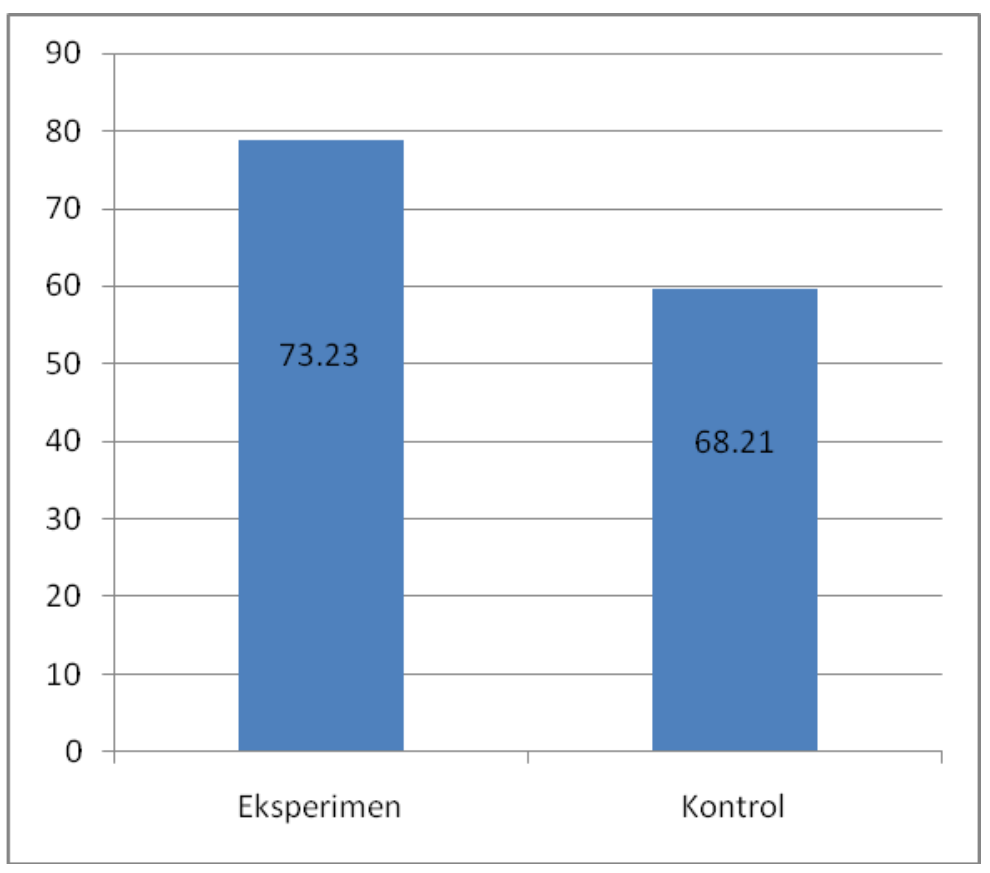

\section{c. Persyaratan Analisis Data Awal (Pre-test)}

1) Uji Normalitas

Uji normalitas dapat digunakan untik mengukur tingkat normalnya suatu data dalam penelitian. Data disebut berdistribusi normal jika $X_{\text {hitung }}<X_{\text {tabel. }}$ Pada penelitian ini, uji normalitas akan diproses menggunakan Chi-Kuadrat, sehingga hasilnya dapat dilihat sebagai berikut. 
Tabel 13

Hasil Uji Normalitas Pre-Test Kelas Eksperimen dan Kelas Kontrol

\begin{tabular}{|c|c|c|c|c|c|}
\hline Variabel & $\begin{array}{c}\text { Jumlah } \\
\text { Sampel }\end{array}$ & $\begin{array}{c}\text { Taraf } \\
\text { Signifikan }\end{array}$ & $\begin{array}{c}\mathrm{X}_{\text {hitung }} \\
\left(\mathrm{X}_{\mathrm{h})}\right.\end{array}$ & $\begin{array}{c}\mathrm{X}_{\text {tabel }} \\
\left(\mathrm{X}_{\mathrm{h})}\right.\end{array}$ & Keterangan \\
\hline $\begin{array}{c}\text { Pretest } \\
\text { Eksperimen }\end{array}$ & 28 & 0.05 & 6.0866 & 7.815 & Normal \\
\hline $\begin{array}{c}\text { Pretest } \\
\text { Kontrol }\end{array}$ & 28 & 0.05 & 6.203 & 7.815 & Normal \\
\hline
\end{tabular}

Suatu data dikatakan berdistribusi normal jika $X_{\text {hitung }}<X_{\text {tabel }}$ dengan $d k=k-3$ dan taraf signifikan 5\%. Dari data di atas dapat dilihat bahwa $\mathrm{X}_{\text {hitung }}$ kedua kelas eksperimen dan control lebih kecil dari $\mathrm{X}_{\text {tabel }}$ dengan $\mathrm{dk}=\mathrm{k}-3=6-3=3$, sehingga dapat disimpulkan bahwa kedua kelas eksperimen dan kontrol setelah diberi perlakuan berdistribusi normal.

\section{2) Uji Homogenitas Varians}

Uji Homogenitas yang dilakukan dengan criteria apabila $F_{\text {hitung }} \geq F_{\text {tabel }}$ berarti tidak homogen, dan jika $F_{\text {hitung }} \leq \mathrm{F}_{\text {tabel }}$ berarti homogen. Dari hasil perhitungan diperoleh nilai varians pretest kelas eksperimen sebesar 60,26 dan varians pretest kelas kontrol adalah 60,83. Sehingga diperoleh nilai $F_{\text {hitung }}=0.99$ dengan taraf signifikansi $a=0,05$ untuk $d k$ penyebut $=5$ dan dk pembilang $=22$ maka didapat $\mathrm{F}_{\text {tabel }}=2,68$. Karena $\mathrm{F}_{\text {hitung }}$ pada pretest kelas kontrol dan eksperimen $0.99<2.68$ dari $\mathrm{F}_{\text {tabel }}$, maka $\mathrm{H}_{\mathrm{o}}$ diterima. Jadi kedua distribusi populasi adalah mempunyai varians yang sama atau homogen.

Tabel 14

Hasil Uji Homogenitas Pre-Test

\begin{tabular}{|c|c|c|c|c|c|}
\hline \multicolumn{2}{|c|}{ Varians } & $\begin{array}{l}\text { Taraf } \\
\text { Signifikan }\end{array}$ & $F_{\text {hitung }}$ & $F_{\text {tabel }}$ & Keterangan \\
\hline Eksperimen & Kontrol & 0.05 & 0.99 & 2.68 & Homogen \\
\cline { 1 - 2 } 60.26 & 60.831 & & 0.96 & \\
\hline
\end{tabular}

\section{3) Uji Perbedaan Dua Rata-Rata}

Analisis yang digunakan adalah uji-t untuk melihat apakah kedua kelas eksperimen dan kontrol tidak mempunyai perbedaan rata-rata dapat dilihat pada tabel berikut ini.

\section{Tabel 15}

Hasil Uji Perbedaan Rata-Rata

\begin{tabular}{|c|c|c|}
\hline Distribusi & $\mathrm{t}_{\text {hitung }}$ & $\mathrm{t}_{\text {tabel }}$ \\
\hline Perbedaan rata-rata & 0.06 & 1.986 \\
\hline
\end{tabular}


Dari data yang didapat disimpulkan bahwa $0.06<1.986$ yang berarti kedua sampel tidak memiliki perbedaan rata-rata yang signifikan. Analisis data awal dapat disimpulkan bahwa kedua kelas eksperimen dan kontrol memilki data yang normal, homogeny atau memiliki varians yang sama dan tidak memiliki perbedaan rata-rata signifikan. Hal ini berarti bahwa kedua kelas ekperimen dan kontrol pada penelitian ini berangkat dari kondisi yang sama.

\section{d. Uji Persyaratan Data Akhir (Post-test)}

\section{1) Uji Normalitas}

Uji normalitas dilakukan untuk mengetahui apakah data yang diperoleh dari masing-masing kelas eksperimen dan kotrol masih berdistribusi normal setelah dilakukan model pembelajaran kooperatif tipe Jigsaw pada kelas eksperimen dan model pembelajaran konvensional pada kelas kontrol. Uji normalitas dilakukan dengan menggunakan rumus chi-kuadrat. Hasil perhitungan uji nomalitas kedua kelas eksperimen dan control dapat dilihat pada table berikut:

Tabel 16

Hasil Uji Normalitas Post-test Kelas Eksperimen dan Kelas Kontrol

\begin{tabular}{|c|c|c|c|c|c|}
\hline Variabel & $\begin{array}{c}\text { Jumlah } \\
\text { Sampel }\end{array}$ & $\begin{array}{c}\text { Taraf } \\
\text { Signifikan }\end{array}$ & $\begin{array}{c}\mathrm{X}_{\text {hitung }} \\
\left(\mathrm{X}_{\mathrm{h}}\right)\end{array}$ & $\begin{array}{c}\mathrm{X}_{\text {tabel }} \\
\left(\mathrm{X}_{\mathrm{h})}\right.\end{array}$ & Keterangan \\
\hline $\begin{array}{c}\text { Pos-test } \\
\text { Eksperimen }\end{array}$ & 28 & 0.05 & 4.356 & 7.815 & Normal \\
\hline $\begin{array}{c}\text { Pos- test } \\
\text { Kontrol }\end{array}$ & 28 & 0.05 & 3.919 & 7.815 & Normal \\
\hline
\end{tabular}

Suatu data dikatakan berdistribusi normal jika $X_{\text {hitung }}<X_{\text {tabel }}$ denga $\mathrm{dk}=\mathrm{k}-3$ dan taraf signifikan $5 \%$. dari data yang telah diperoleh dilihat bahwa $X_{\text {hitung }}$ kedua kelas eksperimen dan kontrol < dari $\mathrm{X}_{\text {tabel }}$ dengan $\mathrm{dk}=\mathrm{k}-3=6-3=3$, sehingga dapat disimpulkan bahwa kedua kelas eksperimen dan kontrol setelah diberi perlakuan berdistribusi normal.

\section{2) Uji Homogenitas Varians}

Uji homogenitas dilakukan untuk mengetahui apakah data nilai awal sampel mempunyai varians yang homogeny (sama). Di bawah ini adalah hasil perhitungan uji homogenitas sebagai berikut: 


\section{Tabel 17}

\section{Hasil Uji Homogenitas Post-test}

\begin{tabular}{|l|c|c|c|c|c|}
\hline \multicolumn{2}{|c|}{ Varians } & $\begin{array}{l}\text { Taraf } \\
\text { Signifikan }\end{array}$ & $\mathrm{F}_{\text {hitung }}$ & $\mathrm{F}_{\text {tabel }}$ & Keterangan \\
\hline Eksperimen & Kontrol & 0.05 & 1.11 & 2.68 & Homogen \\
\cline { 1 - 2 } 78.74 & 70.87 & & 1.11 & & \\
\hline
\end{tabular}

$F_{\text {hitung }}$ diperoleh dengan membandingkan varians terbesar dengan varians kecil. Varians terbesar adalah 78.74 dan varians terkecil 70.87. Suatu data dikatakan homogen apabila $F_{\text {hitung }}<F_{\text {tabel }}$ sehingga diperoleh $1.11<2.68$ artinya kedua kelas eksperimen dan kontrol setelah dilakukan model pembelajaran kooperatif tipe Jigsaw dan model pembelajaran konvensional mempunyai varians yang sama.

\section{e. Uji Hipotesis}

Rumus hipotesis statistik dalam penelitian ini adalah adalah:

$$
\begin{array}{ll}
\mathrm{H}_{0} & =\mu_{1} \leq \mu_{2} \\
\mathrm{H}_{\alpha} & =\mu_{1}>\mu_{2}
\end{array}
$$

Keterangan:

$\mathrm{H}_{0=}$ Hipotesis nol, tidak terdapat pengaruh yang signifikan model pembelajaran kooperatif tipe Jigsaw terhadap hasil belajar Pendidikan Agama Islam pokok bahasan meneladani ketaatan malaikat-malaikat Allah Swt.

Hipotesis alternatif, terdapat pengaruh yang signifikan model

$\begin{aligned} \mathrm{H}_{1}= & \text { pembelajaran kooperatif tipe Jigsaw terhadap hasil belajar } \\ & \text { Pendidikan Agama Islam pokok bahasan meneladani ketaatan }\end{aligned}$ malaikat-malaikat Allah Swt.

$\mu_{1}=$ Nilai rata-rata hasil belajar pokok bahasan meneladani keaatan malaikat-malaikat Allah Swt. yang telah diajarkan dengan model Jigsaw

$\mu_{2}=$ Nilai rata-rata hasil belajar pokok bahasan meneladani ketaatan 
malaikat-malaikat Allah Swt. Yang telah diajarkan dengan metode ceramah di kelas kontrol .

Untuk perhitungan hasil perhitungan hasil pengujian hipotesis, dapat dilihat pada tabel berikut:

\section{Tabel 18}

Hasil Uji Hipotesis Kelas Eksperimen dan Kontrol

\begin{tabular}{|l|r|r|r|l|l}
\hline Kelompol & $\mathrm{N}$ & \multicolumn{1}{l|}{ Mean } & Varians & $\mathrm{t}_{\text {hitung }}$ & \multicolumn{1}{|l}{$\mathrm{t}_{\text {tabel }}$} \\
\cline { 1 - 4 } Eksperimen & 28 & 73.25 & 78.764 & & \\
\cline { 1 - 4 } Kontrol & 28 & 68.21 & 70.87 & \multirow{2}{*}{3.80} & 1.986 \\
\hline
\end{tabular}

Dari perhitungan di atas dapat dilihat bahwa $t_{\text {hitung }}$ lebih besar dari $t_{\text {tabel }}$. Dari hasil penelitian yang dilakukan oleh peneliti diperoleh nilai dengan rata-rata post-test untuk kelas eksperimen 73.23 dengan varians $S_{1}^{2}=176.0$; sedangkan kelas kontrol memperoleh nilai dengan rata-rata 70.87 dengan varians $S_{2}^{2}=115,7$.

Berdasarkan pengujian nilai rata-rata hasil belajar Pendidikan Agama Islam pokok bahasan meneladani ketaatan Malaikat-Malaikat Allah SWT diperoleh harga $t_{\text {hitung }} 3.80$ taraf signifikan $a=0,05$ dan derajat kebebasan $(d b=54)$ diperoleh nilai $t_{\text {tabel }}=1.986$. Hal ini berarti hipotesis di terima yang menyatakan bahwa terdapat pengaruh yang signifikan penggunaan model pembelajaran kooperatif tipe Jigsaw terhadap hasil belajar Pendidikan Agama Islam pokok bahasan meneladani ketaatan malaikat-malaikat Allah SWT. kelas VII di SMP Negeri 1 Angkola Timur.

\section{PEMBAHASAN}

Berdasarkan hasil data penilaian hasil belajar setelah dilakukan pre-test diperoleh nilai rata-rata kelas eksperimen 51,52 dan kelas kontrol 51,15. Sedangkan setelah diterapkannya model pembelajarn kooperatif tipe Jigsaw untuk kelas eksperimendan model pembelajaran konvesional, untuk kelas kontrol dan diberikan post-test untuk mengetahui seberapa besar peningkatan hasil belajar peserta didik pada kelas eksperimen dan kelas kontrol. Data penilaian hasil belajar dapat dikelatuhui rata-rata yang diperoleh dari kelas eksperimen sebesar 73,23.Sedangkan pada kelas kontrol rata-rata yang diperoleh sebesar 68,21. 
Untuk melihat pengaruh dari pendekatan hasil belajar peserta didik antara kelas eksperimen dan kelas kontrol dapat dilihat dari rata-rata post-test pada kelas eksperimen 73,23 dan rata-rata pada kelas control 68,21 dan dapat dilihat juga dari hasil uji normalitas tes akhir pada kelas eksperimen $X_{\text {hitung }}<X_{\text {tabel }}$ dengan nilai $8,7<11,1$ dan nilai akhir pada kelas kontrol $10,1<11,1$. Hal ini sesuai dengan kriteria uji normalitas, maka dapat disimpulkan bahwa data tes akhir berditribusi "normal". Sedangkan uji homogenitas tes akhir menunjukkan $F_{\text {hitung }} \leq F_{\text {tabel }}$ dengan nilai $0,99762<1,90101$. Hal ini sesuai dengan kriteria uji homogenitas, maka dapat disimpulkan bahwa tes akhir berdistribusi "homogen".

Hal ini ditunjukkan dari hasil uji coba hipotesis dimana $t_{\text {hitung }} 3.80$ dengan taraf signifikan $a=0,05$ dan derajat kebebasan $(d b=56)$ diperoleh nilai $t_{\text {tabel }}=198$. Hal ini berarti hipotesis di terima yang menyatakan bahwa terdapat pengaruh yang positif kan signifikan penggunaan model pembelajaran kooperatif tipe Jigsaw terhadap hasil belajar Pendidiksn Agama Islam pokok bahasan meneladani ketaatan malaikat-malaikat Allah SWT kelas VII di SMP Negeri 1 Angkola Timur. Hasil penelitian ini sejalan dengan hasil penelitian Muhammad (2015) dan Susanti (2016) yang menyebutkan bahwa metode Jigsaw dapat mempengaruhi hasil belajar Pendidikan Agama Islam.

\section{KESIMPULAN}

Hasil dari penelitian yang telah dilakukan peneliti adalah menyatakan bahwa terdapat pengaruh yang signifikan dari penggunaan model pembelajaran kooperatif tipe Jigsaw terhadap peningkatan hasil belajar Pendidikan Agama Islam peserta didik. Hal ini ditunjukkan dari hasil

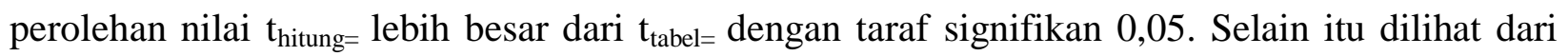
hasil perhitungan pos-test kelas eksperimen menggunakan model pembelajaran kooperatif tipe Jigsaw (rata-rata 73,23), menunjukkan nilai lebih tinggi dibandaingkan dengan kelas kontrol yang menggunakan model pembelajaran konvensional (rata-rata 68.21).

Dengan demikian temuan ini mengindikasikan bahwa untuk mendapat hasil belajar yang baik, maka salah satu langkah yang bisa digunakan guru adalah dengan menggunakan model pembelajaran kooperatif tipe Jigsaw. Dengan pembelajaran kooperatif tipe Jigsaw peserta didik akan lebih memahami materi dan akan lebih mudah dalam menyerap serta memproses pengetahuan secara efektif. 


\section{DAFTAR PUSTAKA}

Arikunto, Suharsimi. Manajemen Penelitian. Jakarta: PT. Rineka Cipta, 2013.

Hajar, Ibnu. Dasar-Dasar Metodologi Penelitian Kuantitatif Dalam Pendidikan. Jakarta: Raja Grafindo Persada, 1999.

Istaraani. 58 Model Pembelajaran Inovatif. Medan: Media Persada, 2014.

Muhammad. "Pengaruh Model Pembelajran Kooperatif Jigsaw Terhadap Tingkat Pemahaman Siswa Tentang Materi Zakat Pada Mata Pelajaran Pendidikan Agama Islam Di Kelas VIII SMP Sulthan Bogor Tahun Ajaran 2015/2016,” 2015.

Mulyasa, E. Menjadi Guru Profesional: Menciptakan Pembelajaran Kreatif Dan Menyenangkan. Bandung: PT Remaja Rosdakarya, 2011.

Rangkuti, Ahmad Nizar. Metode Penelitian Pendidikan Pendekatan Kuantitafi, Kualitatif, PTK, Dan Penelitian Pengembangan. Bandung: Citaputaka Media, 2016.

Rusman. Model-Model Pembelajaran Mengembangkan Profesionalisme Guru. Kedua. Jakarta: PT Raja Grafindo Persada, 2013.

Susanti, Susi. "Peningkatan Prestasi Belajar Pai Meteri Beriman Kepada Malaikat Allah Menggunakan Metode Jigsaw Pada Siswa Kelas VII B Semester 2 SMP Negeri 3 Ungaran Kabupaten Semarang Tahun Pelajaran 2016/2017,' 